\title{
$\mathbf{u}$
}

\section{Global Law \& Plunder: The Dark Side of the Rule of Law}

\author{
Ugo Mattei $^{1}$ \& Marco de Morpurgo ${ }^{2}$
}

${ }^{1}$ UC Hastings, University of Turin \& IUC Turin

${ }^{2}$ International University College of Turin

\section{IUC Research Commons}

Copyright note: Works are posted in this institutional repository, on the understanding that it is permissible for them to be included in open access databases maintained by the authors' respective academic affiliation(s). For any additional queries, please contact the IUC (its [at] iuctorino [dot] it). 


\title{
BOCCONI SCHOOL OF LAW STUDENT-EDITED PAPERS
}

\author{
Bocconi School of Law \\ Student-Edited Papers
}

\author{
Global LaW \& Plunder: The Dark Side of THE RUle of LaW \\ Ugo Mattei \\ Professor, Hastings College of the Law \& University of Turin \\ Marco de Morpurgo \\ M.Sc. Candidate, International University College of Turin; \\ LL.M. Candidate, Harvard Law School
}

\begin{abstract}
The 'rule of law' has traditionally been conceived as an intrinsically positive and politically neutral 'tool', universally valid and capable of being 'exported' everywhere. This paper-which represents a synthetic exposition of the ideas expressed in Ugo Mattei and Laura Nader, Plunder: When the Rule of Law is Illegal (Blackwell Publishing, Oxford 2008) - asserts that such an ambiguous concept has a bright and a dark side, the latter being excluded from any public discussion. The rhetoric of the 'rule of law' has been used by Western powers in order to justify interventions (mainly) into the 'developing' world, that ultimately turned into practices of plunder, allowing the expansion of Western economic power over the 'rest', thus backing a claim that the rule of law has been used 'illegally'. Intellectual myopia, ethnocentrism and imperial attitudes stand behind the conception of the rule of law that currently wraps international financial institutions'-today's global legislators-reform projects in the 'developing world'. The transformation of the concept of 'law' into that of a 'technicality', the globally dominant position enjoyed by U.S. law and the imperial attitude of today's Western international corporate actors are some of the elements that show a pattern of continuity between colonialism and today's neo-liberal policy.
\end{abstract}

\section{BOCCONI SCHOOL OF LAW STUDENT-EDITED PAPERS PAPER NO. 2009-03/EN}

This paper can be downloaded without charge from

Bocconi Legal Papers www.bocconilegalpapers.org 


\title{
GLOBAL LAW AND PLUNDER: THE DARK SIDE OF THE RULE OF LAW ${ }^{\dagger}$
}

\author{
Ugo Mattei $^{*} \&$ Marco de Morpurgo ${ }^{\S}$
}

SUMMARY

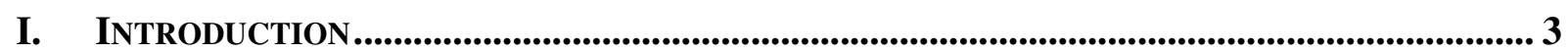

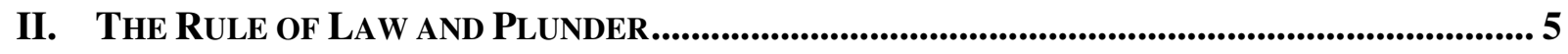

III. The Neo-Liberal Paradigm and the Role of InTERnational FinanCial

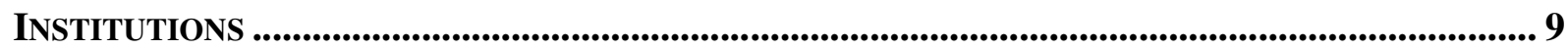

IV. NEO-Classical ECONOMICS AND THE WASHINGTON CONSENSUS ................................. 13

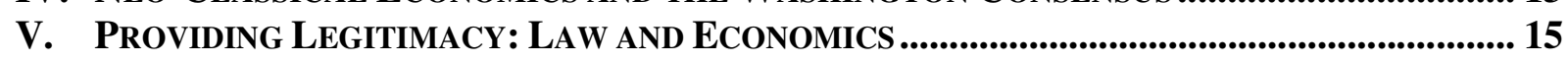

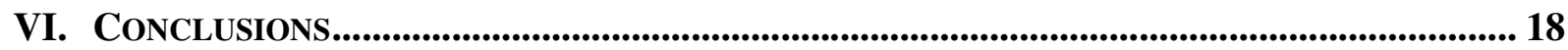

\footnotetext{
$\dagger$ The content of this paper represents a synthetic exposition of the ideas expressed in more detail in Ugo Mattei and Laura Nader, Plunder: When the Rule of Law is Illegal (Blackwell Publishing, Oxford 2008).

*umattei@uchastings.edu

$\S$ demorpurgo@gmail.com
} 


\section{INTRODUCTION}

The increasing expansion of international markets and the contextual decreasing role of states $^{1}$ in the law-making process have made everyone aware of the existence and increasing importance of a 'global law'. Within the current global scenario, the state, to whose authority the main sources of law would traditionally be traced back, has been challenged both from the 'top-down' by global law and from the 'bottom-up' by the local dimension, being confined to a relatively marginal role.

What we can identify as 'global law' is not a single and coherent system of law drawing legitimacy from a well-defined legal and political process. Rather, a mixture of international and transnational instruments and processes-non-democratic institutional settings, power/force relationships and ethnocentric intellectual attitudes_-stand behind the legal rules that are adopted by public and private actors at the global and (consequently) ${ }^{2}$ at the local level. This is not a new phenomenon, although its magnitude has recently been increasing.

Within this framework, Western law has constantly enjoyed a dominant position during the past centuries and today, thus being in the position to shape and bend the evolution of other legal systems worldwide. During the colonial era, continental-European powers have systematically exported their own legal systems to the colonized lands. During the past decades and today, the United States have been dominating the international arena as the most powerful economic power, exporting their own legal system to the 'periphery', both by itself and through a set of international institutions, behaving as a neo-colonialist within the ideology known as neoliberalism.

Western countries identify themselves as law-abiding and civilized no matter what their actual history reveals. Such identification is acquired by false knowledge and false comparison with other peoples, those who were said to 'lack' the rule of law, such as China, Japan, India, and the Islamic world more generally. In a similar fashion today, according to some leading economists, Third World developing countries 'lack' the minimal institutional systems necessary for the unfolding of a market economy.

The theory of 'lack' and the rhetoric of the rule of law have justified aggressive interventions from Western countries into non-Western ones. The policy of corporatization and open markets, supported today globally by the so-called Washington consensus ${ }^{3}$, was used by Western bankers and the business community in Latin America as the main vehicle to 'open the veins' of the continent-to borrow Eduardo Galeano's metaphor - with no solution of continuity between colonial and post-colonial times. Similar policy was used in Africa to facilitate the forced transfer of slaves to America, and today to facilitate the extraction of agricultural products, oil,

\footnotetext{
${ }^{1}$ Although this trend has recently been challenged by the regulatory interventions enacted by states during the current financial crisis.

2 Sometimes according to law-making/unifying/harmonizing institutions' mechanisms, other times following a variety of patterns - that will be discussed below_-of legal transplant and model circulation.

${ }^{3}$ The expression originally indicated the consensus of the World Bank, the International Monetary Fund and the United States Department of Treasury about the policies for development of Latin America during the 1980s. Coined in 1990 by economist John Williamson-J Williamson, What Washington Means by Policy Reforms, in J Williamson (ed), Latin American Adjustment: How much has happened? (Institute for International Economics, Washington, DC 1990)_for indicating such policies, the expression has then come to indicate, in general, any political orientation pursuing development through free-market policies (privatizations, capital market liberalization, reduction of the role of the state in the economy, and so on).

${ }^{4}$ See C Belfrage (tr), Eduardo Galeano, Open Veins of Latin America: Five Centuries of the Pillage of a Continent (Monthly Review Press, New York 1973, reprinted 1997).
} 
minerals, ideas and cultural artefacts in the same countries. The policy of opening markets for free trade, used today in Afghanistan and Iraq, was used in China during the nineteenth century Opium War, in which free trade was interpreted as an obligation to buy drugs from British dealers. The policy of forcing local industries to compete on open markets was used by the British empire in Bengal, as it is today by the WTO in Asia, Africa, and Latin America.

Foreign-imposed privatization laws that facilitate unconscionable bargains at the expense of the people have been vehicles of plunder, not of legality. In all these settings the tragic human suffering produced by such plunder is simply ignored. In this context law played a major role in legalizing such practices of powerful actors against the powerless. ${ }^{5}$ Yet, this use of power is scarcely explored in the study of Western law.

The exportation of Western legal institutions from the West to the 'rest' has systematically been justified through the ideological use of the extremely politically strong and technically weak concept of 'rule of law'. The notion of 'rule of law' is an extremely ambiguous one. Notwithstanding, within any public discussion its positive connotations have always been taken for granted. The dominant image of the rule of law is false both historically and in the present, because it does not fully acknowledge its dark side. The false representation starts from the idea that good law (which others 'lack') is autonomous, separate from society and its institutions, technical, non-political, non-distributive and reactive rather than proactive: more succinctly, a technological framework for an 'efficient' market.

The rule of law has a bright and a dark side, with the latter progressively conquering new ground whenever the former is not empowered by a political soul. In the absence of such political life, the rule of law becomes a cold technology. Moreover, when large corporate actors dominate states (affected by a declining regulatory role), law becomes a product of the economy, and economy governs the law rather than being governed by it.

Contemporary mass cultures operate within a short time-span. Most intellectuals do not acknowledge that it is exactly because of plunder of gold, silver, bioresources and so on that development accelerated in the West, so that underdevelopment is a historically produced victimization of weaker and more enclosed communities and not the disease of lesser people.

Prevailing short-term and short-sighted opportunism must be overcome. An analysis of the imperial adventure rendered in legal terms opens up a possibility for a radical rethinking of a

\footnotetext{
${ }^{5}$ See, for instance, international institutions' interventions for the formalization of property assets in developing countries-for recent developments on the topic see, inter alia, World Bank, Doing Business 2008 (The International Bank for Reconstruction and Development/The World Bank, Washington 2007) or United Nations Commission on Legal Empowerment of the Poor, Making the Law Work for Everyone (Commission on Legal Empowerment of the Poor and United Nations Development Program, New York 2008). The mainstream justification for formalization interventions is well expressed in Peruvian economist Hernando de Soto's bestseller The Mistery of Capital: Why Capitalism Triumphs in the West and Fails Everywhere Else (Basic Books, New York 2000), according to which formalization of 'informally owned' assets would be beneficial for the poor, mainly because it would favour the development of a credit system. Contrary to his position, a wide scholarly production argued that the effects of registration of land can be seriously harmful for the poor: in fact, 'informal ownership' of land is a way of protection against foreign investors, who cannot have access to that property until this is not registered in a 'formal' system. The registration of land-apart from being disrespectful of age-old local traditionsis a way to put it on the market, thus making it available for purchase to whoever is more 'willing to pay' for it, that is - how it will be argued below-who is more able to pay for it. For objections and critiques to international institutions' interventions on property law and the formalization of property assets, see inter alia W Easterly, The White Man's Burden: Why the West's Efforts to Aid the Rest Have Done So Much Ill and So Little Good (Penguin Books, New York 2006) 90-95, David Kennedy, Law and Developments, in A Perry and J Hatchard (eds), Contemplating Complexity: Law and Development in the 21st Century (Cavendish, London 2003) and, for the Latin American experience, JL Esquirol, ‘The Failed Law of Latin America' (2008) 56 Am J Comp Law 75.
} 
model of development defined by Western ideas of progress, development and economic efficiency. A reconfiguration would mean, first and foremost, a clear rejection of an ideology of inherent superiority of Western culture that does not recognize that the West is itself part of something much larger.

\section{The Rule of LAW AND Plunder}

The expression 'rule of law' has gained currency well outside the specialized learning of lawyers. It has reached political and cultural spheres, entering everyday discourse and media language, it is pronounced in countless political speeches and promenades on the agendas of private and public actors.

Unfortunately, the term has incrementally lost clarity and is today interpreted in widely disparate ways. 'Rule of law' is almost never carefully defined as a concept; users of the expression allude to meanings that they assume to be clear and objective but are not so. Rule of law has thus become part of that dimension of tacit knowledge, described by Polanyi in his classic study of human communications. ${ }^{6}$ Naturally, this would be a perfectly innocent and common phenomenon, not worthy of inquiry, were it not for the weighty political implications of the phrase in different contexts.

The connotations of the expression 'rule of law' have always been implicitly positive. Today, the concept is inextricably linked to the notion of democracy, thus becoming a powerful, almost indisputable, positively loaded ideal. Who could argue against a society governed under democracy and the rule of law?

The rule of law lives today in a comfortable limbo, stretched to fit the needs of every side of the political spectrum as a symbol or an icon rather than as a real-life institutional arrangement with its pros and cons to be discussed and understood as those of any other cultural artefact. It is necessary to get to a better understanding of this powerful political weapon, and to question its almost sacred status, by analyzing it as a Western cultural artefact, closely connected with the diffusion of Western political and economic domination.

The rule of law rhetoric has been used as a justification for 'plunder' (broadly definable as inequitable distribution of resources by the strong at the expenses of the weak), thus backing a claim that it has been used 'illegally'. This can be identified as 'the dark side of the rule of law', which is kept silent from any public discussion. In order to deeply understand both sides of the rule of law, the close connection of such concept with the ideal of democracy has to be disentangled, and on the contrary its close association with practices of 'plunder' has to be recognized.

In the dominant liberal democratic tradition the rule of law has at least two different aggregates of meaning. In the first, the rule of law refers to institutions that secure property rights against governmental taking and that guarantee contractual obligations. This is the meaning of rule of law invoked by Western businessmen interested in investing abroad. International institutions such as the World Bank or the International Monetary Fund (IMF) often charge the lack of the rule of law as the main reason for insufficient foreign investment in poor countries.

\footnotetext{
${ }^{6}$ Michael Polanyi, The Tacit Dimension (Peter Smith Publisher, Magnolia 1983).

${ }^{7}$ For power implications of vague meanings, or what he calls 'plasticwords', see Uwe Porsken, Plastikworther. Die Sprache einer internationalen Diktatur (Klenn-Cotta, Stuttgart 1989). For a similar observation on the rule of law as a vague notion, see $\mathrm{G}$ Ajani, Navigatori e giuristi. A proposito del trapianto di nozioni vaghe, in $\mathrm{V}$ Bertorello (ed) Io comparo, tu compari egli compara: che cosa come, perché (Giuffre', Milan 2003) 3-18.
} 
The rule of law is thus interpreted as the backbone of an ideal market economy. Normative recipes for market liberalization and opening up of local markets to foreign investment thus come packaged with the prestigious wrapping of the rule of law.

According to the second approach, which relates to a liberal political tradition rooted in 'natural law' and in the more secular form of 'rational law', society should be governed by the law and not by a human being acting as a ruler (sub lege, non sub homine). The law is impersonal, abstract and fair because it is applied mechanically to anyone in society, and a system is effectively governed by the rule of law when its leaders are under its restraint.

Some conservatives might favour the first meaning, protecting property and contracts. The second meaning, providing rights, is a favourite of the moderate left and of many international human rights activists seeking to do good by the use of the law (the 'do-gooders'). Perhaps someone located in the so-called 'Third world' would claim to be a champion of both meanings, which appear to merge in the recent, comprehensive definition of the World Bank: 'The rule of law requires transparent legislation, fair laws, predictable enforcement, and accountable governments to maintain order, promote the private sector growth, fight poverty and have legitimacy'.

A system can be governed by the rule of law in one or the other sense. There are systems in which property rights are worshipped but that are still governed by ruthless, unrestricted leaders. President Fujimori's Peru or Pinochet's Chile are good recent examples of such arrangements, but many other authoritarian governments presently in office mainly in Africa, Asia and Latin America that follow the 'good governance' prescriptions of the World Bank also fall in this category.

In other systems, with good human rights credentials, governments interpret their role as significantly redistributive. Property rights may not be sacred, and a variety of 'social theories' may limit their extension or curtail them without compensation. In such settings, quite often, courts and scholars might develop theories that limit the enforcement of contracts in the name of justice and social solidarity. Consequently, they might fit the second but not the first definition of the rule of law. Scandinavian countries, amplifying attitudes shared at one time or another in history by a number of continental legal traditions such as France, Germany and Italy (or the United States' New Deal), might offer such a model in Western societies.

Western countries have developed a strong identity as being governed by the rule of law, no matter what the actual history or the present situation might be. Such identity is obtained-as is the usual pattern — by comparison with 'the other', almost invariably portrayed as 'lacking' the rule of law.

Based on the idea that others 'lack' the rule of law, many external interventions have been enacted in the so-called 'developing countries' by Western actors. Many of such interventions, instead of being beneficial for the local society, have shown the possibility for the law to be used as an instrument of oppression and plunder, ironically representing an 'illegal' use of the rule of law. ${ }^{9}$

\footnotetext{
${ }^{8}$ See World Bank, Initiatives in Legal and Judicial Reform (The World Bank, Washington, DC 2004), 4.

${ }^{9}$ In 'developing' countries, wide sectors of the economy do not follow state 'formal' law. Rather, these sectors, which are usually referred to as 'informal economies'—see H de Soto, The Mistery of Capital (n 5)—are ruled by a spontaneous, often customary, 'informal' law. Thus, in these contexts national economies are divided between a 'formal' and an 'informal' sector, the former being governed by state law and the latter by an 'informal law'. For this reason, when legal reforms are implemented, the law changes only at the formal level, not producing any change for the informal economy. Rule-of-law and free-market inspired interventions on the legal system, therefore, are usually beneficial, if at all, only for the 'formal' economy (local elites) and for international corporate actors, but
} 
Historically, the Western conception of the rule of law, serving the expatriate community, international investors and the desire to organize authoritarian power more effectively, was imposed upon China and Japan in the late nineteenth and early part of the twentieth century in order to 'open up' the Asian market for foreign plunder. Earlier, throughout the American continent, the 'lack' of individual ownership justified the taking of Indian lands deemed vacant by the Western 'discovery' principle. Recently, the rule of law, still an undefined and undertheorized concept, has mightily been sponsored by the so-called structural adjustment plans (SAPs), the instruments used by the international financial institutions (World Bank and IMF) for conditioning their loans. ${ }^{10}$

There is a clear pattern of continuity, not of rupture, between the current policy trend in the international institutional setting and earlier practices, in particular colonialism. The Western world, under current U.S. leadership, having persuaded itself of its superior position, largely justified by its form of government, has succeeded in diffusing rule of law ideology as universally valid, behind whose shadows plunder hides, both in domestic and in international matters.

Present-day international interventions led by the United States are no longer openly colonial efforts. They might be called neo-colonial, imperialistic or simply post-colonial interventions. Although practically all of European colonial states (most notably Portugal, Spain, Great Britain, France, Germany and even Italy) regarded themselves as empires, the concept of 'empire' is what best describes the present phase of multinational capitalist development with the USA as the most important, hegemonic superpower, using the rule of law to pave the way for international corporate domination.

Export of the law can be described and explained in a variety of ways. A first example is the imperialistic/colonial rule, or imposition of law by military rules, as during military conquest: Napoleon imposed his Civil Code to French-occupied Belgium in the early nineteenth century. Similarly, General MacArthur imposed a variety of legal reforms based on the American government model in post World War II Japan, as a condition of the armistice in the aftermath of Hiroshima. Today, Western-style elections and a variety of other laws governing everyday life are imposed in countries under US occupation, such as Afghanistan and Iraq.

leave completely unchanged the legal system governing the 'informal economy'. Furthermore, these reforms are likely to produce negative effects on the informal sector, when 'formalizing' sectors of the economy, which pass from being a resource for the people to being exploited by foreign corporate actors (see nt 5).

${ }^{10}$ The 'real' period of World Bank-sponsored 'structural adjustments' was the 1980s. The 1990s have then been referred to as the 'governance' period. Since 1999, the 'structural adjustment' and then 'governance' paradigms have formally been replaced by the so-called 'comprehensive development' phase, inaugurated by President James D. Wolfhenson's strategy of a Comprehensive Development Framework (CDF) — J D Wolfhenson, A Proposal for a Comprehensive Development Framework (May 1999) available at $<\mathrm{http}$ //siteresources.worldbank.org/CDF/Resources/cdf.pdf>- CDF seeks to reconceptualize development by going beyond its macroeconomic and financial aspects to focus on structural, social and human concerns. Notwithstanding, it has been pointed out that no substantial change has occurred, the shift to a 'comprehensive development' phase being a mere shift in the legitimizing rhetoric for external intervention. On this view, see A Santos, The World Bank's Uses of the 'Rule of Law' Promise in Economic Development, in DM Trubek and A Santos (eds), The New Law and Economic Development, a Critical Appraisal (Cambridge University Press, New York 2006) 267. 
A second model can be described as imposition by bargaining, in the sense that acceptance of law is part of a subtle extortion ${ }^{11}$. Target countries are persuaded to adopt legal structures according to Western standards or face exclusion from international markets. This model describes the experience of China, Japan and Egypt in the early twentieth century, and, indeed, contemporary operations of the World Bank, IMF, the World Trade Organization (WTO) and other Western development agencies (United States Agency for International Development (USAID), European Bank for Reconstruction and Development (EBRD), and so on) in the 'developing' and former socialist world.

A third model, constructed as fully consensual, is diffusion by prestige, a deliberate process of institutional admiration that leads to the reception of law. ${ }^{12}$ According to this vision, because modernization requires complex legal techniques and institutional arrangements, the receiving legal system, more simple and primitive, cannot cope with the new necessities. It lacks the culture of the rule of law, something that can only be imported from the West. Every country that in its legal development has 'imported' Western law has thus acknowledged its 'legal inferiority' by admiring and thus voluntarily attempting to import Western institutions. Turkey during the time of Ataturk, Ethiopia at the time of Haile Selassie and Japan during the Meiji restoration are modern examples.

Interestingly, if the transplant 'fails', such as with the attempts to impose Western-style regulation on the Russian stock market, or as with many law and development enterprises, it is the recipient society that receives the blame. Local shortcomings and 'lacks' are said to have precluded progress in the development of the rule of law. When the World Bank produces a development report on legal issues, it invariably shows insensitivity for local complexities and suggests radical and universal transplantation of Western notions and institutions.

Recent examples of plunder disguised by the rule of law rhetoric, and thus by the use of law as a façade of legitimacy, can be found in the 2002 Argentinean crisis ${ }^{13}$, the extraction and management of oil in Iraq and elsewhere ${ }^{14}$ and in the numerous situations in which intellectual property law, as conceived and imposed by the WTO (based on an ethnocentric individualistic conception of the intellectual creation), denies any benefit to the real inventors (e.g. when they are a community with age-old traditions) and entitles profits to Western corporate actors that have 'stolen' the idea by patenting what for others is part of their widespread knowledge. ${ }^{15}$ This happens when ideas are stolen from other cultural traditions: because they do not have a status of intellectual private property there, they can be legitimately patented by Western firms, where they do have such a legal status. Automatically, they then no longer 'belong' to the group from whom they originated.

\footnotetext{
${ }^{11}$ Also recently described as 'context of conditionality'. See Sally Falk Moore, An international regime and the context of conditionality, in M Likosky (ed), Transnational Legal Process (Macmillan Publishers, London 2002), 33.

12 This is the classic theory of Alan Watson, Legal Transplants: an Approach to Comparative Law (University of Georgia Press, Athens, GA 1974). On the notion of prestige, see also Rodolfo Sacco, 'Legal Formants: A Dynamic Approach to Comparative Law - Installment I of II' (1991) 39 Am J Comp Law 1; and, more critically, Elisabetta Grande, Imitazione e Diritto (Giappichelli, Torino 2001).

${ }^{13}$ See Ugo Mattei and Laura Nader, Plunder: When the Rule of Law is Illegal (Blackwell Publishing, Oxford 2008) 35-42.

${ }^{14}$ See ibid 111-19.

${ }^{15}$ See ibid 83-88.
} 


\section{The Neo-Liberal Paradigm AND the Role OF InTERnational FinanCial INSTITUTIONS}

It is often said that the 2002 Argentinean crisis was favoured by the Washington Consensus or neo-liberal policy. But what is neo-liberalism? What are its roots? Who are the actors implementing its political projects? How does neo-liberalism relate to plunder and the rule of law?

Neo-liberalism can be seen as a revolutionary theory accompanied by praxis. Just as the building of socialism in the Soviet Union was the product of a theory (Marxism) and praxis (Leninism), reacting against a deeply grounded political order (Russian czarism), similarly neoliberalism is the product of theory and praxis reacting against a previous order, the welfare state. This simple parallel is sufficient to show how the Regan/Thatcher revolution, which spawned the neo-liberal praxis, can be seen as a reactionary move. The neo-liberal revolution targeted progressive social and political settings. It has reacted against a frontier of institutional developments, the so-called welfare state, and against the accompanying attempt to build, in a complex society, a structure capable of responding at least in part to the needs of its weaker members. Neo-liberal theory blamed inefficiency on the welfare state. Neo-liberal praxis has been grounded in privatization, deregulation, downsizing, outsourcing and taxation cuts.

Consequently, neo-liberalism can be considered to be, more than a revolution, a restoration of the nineteenth century political setting, in a society that for the first three quarters of the twentieth century had moved worldwide in the direction of more socially concerned models of development. Theories of the 'social' in legal and political thinking began to unfold in the latter part of the nineteenth century and became a dominant pattern of legal and political thought by the second decade of the twentieth century. ${ }^{16}$ These social models put at the centre of the picture the social group (or the state), but to better serve the individual in society: affirmative rights rather than negative liberties. These social models originated in French and German political thought and in the Scandinavian praxis, but spread well beyond the contours of the Western legal tradition. We can find welfare state theories in Catholic solidarity thinking, in the intellectual imaginary of the Second International, in Egyptian modernization efforts, in Mexican revolutionary rhetoric, in Argentinean Peronism and, of course, in the social platform of Teddy Roosevelt and Franklin Delano Roosevelt. These theories certainly display a notable component of ambiguity, to the point of often being functional to bolster authoritarian and even fascist regimes. Nevertheless, after the horrors of World War II, social theories were purified of their degenerations; they were enriched by Keynesian economics, and provided an ideal of advanced, progressive society throughout the capitalistic bloc.

With the raise of the political and economic theory of neo-liberalism, the welfare state, rather than being seen as one of the most advanced frontiers of human civilization that capitalism could attain, began to be considered a wasteful bureaucratic organization to be abandoned as rapidly as possible. Since then, state legislation has been challenged as corrupt and captured by special interests. Exploiting the ambiguous relationship between socialism and the social, political and economic theories grounding the welfare state, neo-liberalism emphasizes the value of individual freedom and portrays the state as the enemy of private property and self-determination. An activist progressive and proactive government attempting to redistribute some public wealth among social classes is presented as a violation of the rule of law.

\footnotetext{
16 See Duncan Kennedy, 'Two globalizations of law and legal thought 1850-1968' (2003) 36 Suffolk Law Review 631
} 
This simplistic platform, based on notions of sanctity of private property and free enterprise, has effectively revived notions of 'freedom of contract' as a limit to state intervention that courts of law had considered obsolete since the 1930s even in the United States.

The trend in policy towards the reduction of the role of the state in the economy, and the enhancement of the protection of property rights and contracts through a 'strong' legal system (rule of law), has characterized, on the one hand, bipartisan legal and economic recipes in the Western world and, on the other hand, the true 'economic constitution' of the post-Cold War international assertion of power known as the Washington Consensus.

The simultaneous revamping and reconstruction of the institutions of global financial stability - the IMF and the World Bank-, that the Anglo-American winners of World War II had created at Bretton Woods in 1944, transformed international financial institutions into global legislators, by theoretically transforming the very idea of law, from a political artefact into a neutral technology. Without such paradigm shift the interference of the Bretton Woods institutions with targeted legal systems would have been impossible to legitimize, given the fact that their bylaws expressly forbid political interventions. ${ }^{17}$

Justifying legal reforms with the idea of the need to create a solid legal framework (rule of law) for the development of market economies, the World Bank and the IMF have implemented, thanks to the mechanism of 'conditionality', a wide and radical series of reforms throughout the 'developing world'. The trend has been to deregulate, downsize, outsource and privatize.

What is most important to observe is that international financial institutions, when intervening as global legislators imposing legal and judicial reforms, have been completely insensitive to the local complexities that characterize targeted countries. The high level of self-confidence that characterizes the West determines a universalistic attitude, which denies context specificity. Universalism and double standards ${ }^{18}$ are reflected in the unfolding conception of the rule of law. Furthermore, in pursuit of a neo-liberal world, the rule of law is considered as a universal minimal legal system offering the best possible model of development. The Bretton Woods institutions, transformed into global legislators by the contractual power to condition international financial aid to domestic law reform, have played a major role in transforming the rule of law into an instrument of plunder in the interest of large international investors.

Keynesian economics, the leading doctrine behind the welfare state with its strong link with politically supported legislation and regulation, came under attack at the same moment in which a conception of the law as an aggregate of technical and neutral private law rules, to be evaluated in terms of economic efficiency rather than substantial justice, became dominant in the United

\footnotetext{
${ }^{17}$ The Articles of Agreement of the International Bank for Reconstruction and Development (IBRD, later World Bank), available at <http://siteresources.worldbank.org/EXTABOUTUS/Resources/ibrd-articlesofagreement.pdf>, contain three provisions intended to prevent political intervention of this institution in member countries and to prohibit it from taking political or non-economic considerations into account. These are Article III, Section 5(b); Article IV, Section 10; and Article V, Section 5(c) of the IBRD Articles. Article IV, 3(b) of the articles of agreement that founded the IMF (available at <www.imf.org $>$ ) contains similar provisions, requiring the Fund to 'respect the domestic social and political policies of members'. On the expansion of the World Bank's competences without violating its mandate, see A Santos, The World Bank's Uses of the 'Rule of Law' Promise in Economic Development (nt 10) 269; and Ibrahim Shihata, The World Bank and 'Governance' Issues in its Borrowing Members, in 1 The World Bank in a Changing World 53 (1991) 85.

18 'Double standards' provide justification for considering unacceptable in certain contexts what in other contexts is perceived as perfectly legitimate. Legal and economic policy supported by international financial institutions is often based on a double standard: for instance, when Western countries defend their protectionist policies while imposing open policies on weaker countries. For some examples, see U Mattei and L Nader, Plunder (nt 13) 130133.
} 
States. As a consequence of this intellectual paradigm, law and institutions became new targets for the World Bank and IMF interventions, breaking a long-established taboo against intervening in the law, which was perceived as a key aspect of the political process of recipient countries. The law was now neutral and technical. It could be targeted, modified and fixed, directly or indirectly, in the same way in which it is possible to intervene to fix a sewer system or a hospital.

Neo-liberal economists and lawyers trained in law and economics became the most powerful advisers of the World Bank and the IMF, in developing their recipes of 'good governance'. Since dismantling is easier than constructing, such advisers busily showed how easy it is to change complex aggregates of local institutions in favour of market friendly ones. The concept of law that dominates the economists' discourse is indeed so simple as to be universal. Economists have traditionally been impatient with the complexities that occupy lawyers. To them, legal complexity as an aggregate of a variety of context-specific institutional and political structures, as well as the local political and legal process, is only a source of transaction costs, which discourages investments and the efficient allocation of resources. According to their vision, the law should facilitate rather than restrict market transactions. Thus, local institutional settings should be 'adjusted' in order to facilitate the free flow of resources from who values them less to whoever values them more (in order to reach an 'efficient allocation').

In these adjusting exercises, collectively known as structural adjustment programs (SAPs), the political process plays no role. Indeed, the strategy is exactly to focus on the 'merely technical' nature of the simple changes that are required in order to secure transfers of property to the most efficient users. It is difficult not to see how such efficient transfers are deeply connected to the initial endowments of resources. Indeed, the 'willingness to pay' for a given resource, the yardstick that economists use in order to see whether such a resource is actually in the hands of whoever values it most, is a function of the 'capacity to pay', which in turns depends on the amount of resources already available to each of the actors of the transaction. Consequently, the rich are systematically favoured when policy is evaluated in terms of economic efficiency, which explains the enormous increase in the gap between the rich and the poor under neo-liberal globalization. Global neo-liberalism applies the logic of 'willingness to pay' to all resources wherever they might be located. In the neo-liberal scheme, all resources, such as knowledge, land and labour, wherever located, must be available for whoever is willing to pay for them. Any measure to defend local policy-making is condemned as an attempt to close the market, an anathema for neo-liberal policy.

Economic policies underlying structural adjustment are thus promoted as responding to higher universal needs and standards, those of efficiency and economic growth, which are defined as superior to those local interests that the (local) political process usually attempts to satisfy. The (local) political process is then provided with a new first priority: the implementation of the 'simple' institutional conditions capable of grounding an efficient marketplace for corporate actors. SAPs-recently renamed comprehensive development frameworks-drafted by the international financial institutions are implemented and enforced by direct (more recently, 'participated') economic conditioning, thus reaching the local political process with irresistible power, being poised beyond reach of both government and opposition parties. Indeed, they can only be evaluated and judged by macro-growth and other indices, interpreted by the financial groups of the IMF, World Bank and of private rating agencies. ${ }^{19}$

${ }^{19}$ See, for instance, the 'Doing Business' reports of the Rapid Response Unit of the World Bank-freely downloadable at $<w w w$.doingbusiness.org $>$ - The Doing Business reports provide measurements and rankings of business regulations and their enforcement across 181 national economies and others at the sub-national and 
It is important to stress that while this key neo-liberal strategy is more visible and more direct in developing transitional countries, it is by no means limited to them. Even in contexts traditionally within the centre, like Germany for example, the logic of neo-liberalism has not been less influential in determining winning political platforms in the aftermath of the Cold War.

Neo-liberal politics, precisely because they privilege the universal needs of market order over the local needs of the political constituency, are often unpopular and spark resistance. Despite the empty rhetoric of 'equitable development', the losers in neo-liberal globalization processes are the weakest layers of the population, such as already impoverished farmers forced to buy genetically modified seeds that work only for a cycle, small shopkeepers displaced by the global chains of distribution, blue collar workers forced to accept pays cuts so as to not lose their jobs. Typically, such a large number of losers are alienated from an electoral process dominated by the rich and by corporate investment. In the United States, more than 80 percent of individual contributions to politics come from the top 0.25 percent of the population; in this model of democracy, corporate actors outspend by more than 10 times trade unions and other non-profit organizations. According to an 'economic' reading of democracy, contributions to the political process are seen as investments so that it is natural that their returns favour whoever made such investments. What follows is the irrelevance of the electoral process for whoever cannot afford to invest into it. This is by no means limited to US politics. An inverse relationship between the degree to which neo-liberal policies are implemented and people's participation in the electoral process is easy to detect worldwide.

Structural adjustment has long been the tool to implement development policies with the stick of conditionality. More recently, structural adjustment, a notion deeply resented by many borrowing countries, has been renamed comprehensive development, broadening even more the subject matter of non-strictly financial intervention. Conditionality has also been renamed, with another move in the direction of politically correct, participatory approach, but it would be difficult to locate actual policy changes. The original idea, advanced by Lord Keynes at Bretton Woods, of worldwide economic stability and ordered growth, under the umbrella of a bank and a fund with a role of intervention to sustain distressed economies, was changed only once in the early 1980s into a model of world governance by transnational, unaccountable, law-making political actors.

At Bretton Woods, participating countries agreed to submit to a degree of international economic discipline, but received guarantees of non-interventions in internal political matters. ${ }^{20}$ The re-definition of the very concept of law and the very change of attitude of the Bretton Woods institutions during the Regan/Thatcher revolution has since then allowed interventions on the legal systems that have been essentially political. Structural adjustment is essentially the contractual agreement by which developing countries give up economic and legal sovereignty in consideration for financing. Because the desperate need for financing in the third world has long been created by strong economic and political actors, themselves dictating the economic policies of the Bretton Woods institutions, such contractual agreements are affected by an imbalance of

regional level. The Doing Business reports, highly influenced by the 'legal origins' scholarly movement and characterized by a very Western (common law)-centric attitude, claim to have 'discovered' which are the universally most efficient legal solutions and thus promote their adoption indistinctively to all countries in the world, proposing them as best practices for business.

20 See, for example, Article IV, 3(b) of the articles of agreement that founded the IMF, available at <www.imf.org>, as well as Article IV, sec. 10 of the agreement establishing the International Bank for Reconstruction and Development termed 'political activity prohibited', available at $<\mathrm{http}: / /$ siteresources.worldbank.org/ibrd/>. 
powers. ${ }^{21}$ Consequently, they frame the law to serve the interests of the stronger actors, thereby operating to transform the rule of law into a facilitator of plunder and an instrument of social oppression. Naturally, the rhetoric of the rule of law serves its powerful ideological role and it is by no means abandoned.

Today, the IMF and the World Bank base their lending to underdeveloped economies on certain predetermined conditions. Such conditions, in theory, should enable the adjusting country to change the structure of its economy so that in the long run it can meet the needs of efficient utilization of the factors of production to ensure sustained growth. In practice, this pompous description means that once economic sovereignty is handed over to the international financial institutions, the political economy of a state must be restructured along the lines of neo-liberal orthodoxy. This implies that 'the role of the State in all its progressive and social welfare functions is being sharply reduced, and the economies themselves have been opened via trade and financial liberalization to the unimpeded forces of world market competition'. ${ }^{22}$

With this clear strategy in the developing world, and a similar one for Western economies, the international financial institutions exercise today tremendous political power worldwide, outside of any kind of control except the will of their majority shareholder. One should appreciate, in order to avoid maintaining the discussion at a senseless abstract level, that the international financial institutions - not imagined as outright political actors in the days of their establishment at Bretton Woods in 1944-are not structured to function as political institutions. Consequently, and quite naturally, they do not maintain any space for democratic legitimacy. Being organized as hierarchies along the model of the Anglo-American public company, a chief executive officer (CEO) and a board are in charge of strategic decision-making that is then implemented by a hierarchical structure, acting with a variety of advisory boards, as in any other kind of complex economic organization.

\section{NeO-Classical Economics AND THE WASHINGTON CONSENSUS}

Structural adjustment programs are grounded in a straightforward version of the so-called orthodox neo-classical view of economics, in particular the undisputed 'efficiency of free markets' and private producers, and the benefits of international competition and trade disregarding power disparities. Economic policies are imposed by means of conditionality. Behind a faked political neutrality and technocracy serving universal interests, this policy hides a political platform in pursuit of the interest of the wealthy few countries holding the majority votes at the IMF and World Bank. The World Bank and IMF are connected today with the WTO, the United Nations and with other international organizations offering an image of general interest while in reality serving the interests of their majority shareholders.

Orthodox neo-classical economic theory (including its perception of the rule of law) is the most powerful legitimizing ally of the Washington Consensus, and is offered as 'proof' of the sound nature of conditionally imposed SAPs or 'participated' comprehensive development frameworks. These plans are indeed based on the essential economic concept of equilibrium between supply and demand. Corporate free market and free trade are considered the best methods for achieving an efficient equilibrium. In order to reach such a result, two kinds of

\footnotetext{
${ }^{21}$ The best description of SAPs available is the movie by Stephanie Black, Life +Debt (2001), discussing SAP and neo-liberal policy in Jamaica.

22 JL Dietz, 'Debt, international corporations and economic change in Latin America and the Caribbean' (1987) 55 Latin American Perspectives 509.
} 
reforms are imposed, external ones and internal ones. Such reforms are imposed by the empirically starved model of supply and demand used to show how free markets-that is, markets allowed to find equilibrium through the unimpaired interaction of supply and demandwill produce the most efficient outcome, not only for a given product (e.g. oil) but, in aggregate, for the economy as a whole.

Internal reforms interpret legislation and state participation in the economy as disrupting the achievement of an efficient equilibrium because legislation introduces practices limiting free competition. In the neo-classical model, barriers to entry in a given industry particularly threaten the natural attainment of an efficient equilibrium point. The assumption being, once more, that competition is the best recipe for efficient equilibrium. Measures to increase efficiency must thus reduce barriers to entry and promote competition. This theory provides a rationale for privatization and liberalization programs. Hence, structural adjustment invariably contains measures to disaggregate the supply side through denationalization, removal of state subsidies and massive privatization. This, in turn, allows cutting taxes since state-run redistribution for the sake of social justice is itself inefficient, and welfare functions are privatized; therefore the state needs less tax revenue. The social costs of such policy might be lethal. For example, the privatization of the railway service from Dakar (Senegal) to Bamako (Mali), acquired by a Canadian-based corporation, has caused the closing of a large number of stations around which small local markets and villages developed over time. ${ }^{23}$ This informal economy, crucial for the survival of many people, has consequently collapsed, leaving thousands of starving peasants facing the possibility of using the train to take their products to larger markets.

External policy reforms are approached too. Here the neo-classical model develops the socalled 'theory of comparative advantages', which 'conclusively' demonstrates the superiority of unrestricted, spontaneous free trade. In a nutshell, the idea is that if international trade barriers are abated, each country will end up specializing in the outputs it produces most efficiently (e.g. cheap labour, coffee, or lumber). Each country will find it cheaper to purchase products on the international market using the revenue from international sales of products that it is better fit to produce. In other words, according to this idea, it is senseless to attempt the production of coffee in Finland. The Finnish would be better off buying coffee in Colombia, while specializing in producing canned herring and cell-phones. While the argument seems persuasive, it proves to be so simplistic as to lose any policy potential in the real world, particularly because of the double standards used by developed economies when implementing trade liberalization policies, providing an immoral justification of the inhuman exploitation of cheap labour that obliges billions of people to work for salaries that do not afford subsistence.

The aggregate of internal and external reform plans, that is the governance of target markets in their internal functioning and in their degree of 'openness' to international competition, imposes a downsizing of the public sector, with consequences faced by the poor ${ }^{24}$ Development plans indicate five major areas of reform and imperatives: 1) allow free markets to determine prices; 2) reduce state control of prices; 3) divest resources held by the state into the private sector; 4) reduce the state budget as far as possible; 5) reform state institutions (courts and bureaucracy) in order to facilitate the private sector (good governance and the rule of law). These five imperatives are accompanied in SAPs by detailed policy prescriptions such as abolition of minimum wages, ending food subsidies (e.g. Mexican corn), reduction of labour security

\footnotetext{
${ }^{23}$ See Ugo Mattei and Laura Nader, Plunder (nt 13) 128-129.

${ }^{24}$ Bob Milward, What is structural adjustment? in G Mohan and others, Structural adjustment. Theory, Practice and Impact (Routledge, London 2000) 33.
} 
standards, contracting out public services (transportation, educations, healthcare, pensions, etc.) to the private sector and the transfer of public resources and operations to corporate actors.

\section{Providing Legitimacy: LAW AND Economics}

As it has been pointed out, orthodox neo-classical economics has been the main legitimizing ally of the Washington Consensus and adjustment interventions in developing countries.

Economics is widely perceived as the 'queen of social sciences', and is the only one recognized as a 'true science'. Not surprisingly, within the neo-liberal project, economists have become more and more influential in policy-making, providing 'neutrality', 'scientific knowledge', 'objectivity' and ultimately a powerful intellectual justification for the ban of redistribution of wealth in society.

Although economists can differ much among themselves in political beliefs, they almost unanimously share a faith in positivism. Furthermore, universality is an important aspect of the behavioural 'laws' that economists describe, so that economics can be considered to be the same in New York, Paris or Bombay. Although some economists assert that account of institutional and cognitive constraints matters, and have consequently paid more attention to the institutional or even cultural context of their prescriptions, ${ }^{25}$ the sense is still that local fundamental differences do not affect the validity of the 'universal laws' according to which markets work. Institutional differences can be tackled in the normative dimension by harmonizing, in order to obtain some universal conditions of efficiency. Alternatively, differences can be 'exploited' within a competitive pattern itself aimed at efficiency. Notions of 'good governance' and 'structural adjustment' share the belief in an evolutionary path of development that poor countries should take in order to reach the 'optimal conditions' of market capitalism.

Although economics, as a scholarly discipline, is a highly sophisticated and formalized one, when it posits itself as a merely 'technical', 'objective' and 'universal' science, it ultimately leads to very simplistic views. Policy prescriptions derived from economists (think of the Chicago Boys in Chile), being ultimately political, must be discussed and criticized in political terms. Even when in good faith, and even when open to the cutting edge of the discipline's developments (paying due attention to institutional and cognitive biases), economists invariably present peripheral countries as so feeble that they are not even able to accomplish very basic recipes for economic success and development. ${ }^{26}$ The mainstream economic profession has thus deeply internalized, ultimately because of its utilitarian axiology, both the self-congratulatory attitude of the West and its condescending, humiliating and often racist attitude towards the rest.

Equally simplistic are the shared perceptions within the economic profession of the reality of the legal system, both in Western settings and a fortiori in peripheral countries. Nevertheless, as often happens, short of being understood as a disciplinary limit, simplistic analysis and simple prescriptions are key to success of a literary genre. Thus economics pundits transmitting such dominant, simple-minded approaches to the general debate through newspapers and other media are relevant here as influential policy-makers and legitimizers of the global 'rule of law'.

This logic was further strengthened by the encounter of interest between the legal and economics professions, happened at the height of the Cold War, when an anti-formalist type of legal reasoning, known as American legal realism, intellectually dominated the US legal culture.

\footnotetext{
25 See Douglas North, Institutions, Institutional Change and Economic Development (Cambridge University Press, Cambridge 1990).

${ }^{26}$ Hernando de Soto is the best-known representative of this simplistic line of thinking.
} 
In the realist vision, the lawyer was to operate as a social engineer, balancing conflicting interests and thus 'creating' the legal framework for future social interactions. According to the realist vision, lawyers should immerse themselves in the study of social interactions to search for the best possible institutional solutions. For this purpose, lawyers needed the guidance of other social scientists, such as anthropologists, or economists. Karl Llewellyn, for example, a leading legal realist, knocked at the door of anthropologist E. Adamson Hoebel to explore forms of 'legal life' outside libraries. ${ }^{27}$ And many other realist lawyers, too, felt that non-lawyers were needed in the law faculties in order to develop non-textual paradigms of thought. Among such non-lawyers appointed to teach in the most prestigious law schools in the 1950s, we find many of the founding fathers of 'law and economics', leading Chicago economists such as Aaron Director or Ronald Coase.

Many American lawyers, particularly those located on the more conservative side of the political spectrum, felt that decades of dominant legal realism required a restructuring of the lawyer's legitimacy as a neutral umpire. The law, they held, needed to be refurbished, reclaiming some objectivity and neutrality if legal scholars and judges were to keep a social role as 'hidden law givers' in a politically legitimized representative system of government.

Economics could offer a good guide outside the black letter of the law and a new strong source of legitimacy. After all, economists were dealing with incentives, which meant focusing on the behaviour of the recipients of legal precepts-something happening beyond the legal text. Economists, moreover, beginning in the 1950s, applied their 'scientific' analysis to the behaviour of politicians and other institutional actors. By claiming that politicians are rational maximizers of their chances to be re-elected, they developed an approach know as 'public choices', claiming to be able to predict the content of legislation and regulatory activity by focusing on the connection between legislators and special interests. By so doing they were still focusing on something outside the legal text understood as the outcome of the political process. Their worry centred on the production of norms, on law in the making, the processes and the forces determining its content. While traditionally lawyers were focusing on legal norms and precepts as they are (or as they should be), economists were claiming that the focus should turn on what comes before (public choices) and after (incentive-reactive behaviour) the legal precept. The focus should be on the process and on the social consequences of its outcome.

As to legitimacy, economics handbooks were full of rhetoric grounded in science and objectivity. The early success of economic reasoning in legal matters can thus be justified by at least two factors: 1) once the focus is on the process, then all would accept that the process should be efficient; and 2) efficiency was claiming objectivity, something essential in a strategy of legitimization. While justice is the domain of subjective feelings, efficiency is the domain of objectivity based only on a few simple, clearly spelled out criteria. ${ }^{28}$

Economists had an agenda too, so the dialogue with lawyers not only served the need to provide legitimacy to the lawyer's role but also would eventually further the political role of the economist by involving them in law-making and legal interpretation.

The economic approach to legal reasoning soon achieved a global role, and this would have not been so if it had not been leveraged, beginning in the Reagan years, by a fully fledged political agenda capable of financing any movement giving cultural prestige to deregulation and other reactionary policies of those years. It is sufficient to look at the early, very lukewarm

\footnotetext{
${ }^{27}$ See Laura Nader, The Life of the Law (University of California Press, Berkeley, CA 2002).

${ }^{28}$ For elaboration, see Ugo Mattei, Comparative Law and Economics (University of Michigan Press, Ann Arbor 1997).
} 
reception of these new ideas in Europe to understand how much lawyers were willing to resist efficiency and privatization in the name of justice and distribution. But the multiplication of academic chairs, endowed research facilities, fellowships and the like in a prestigious context like the United States academia (today's global graduate school) was a certain recipe for global success, including its spread to China, India and elsewhere.

Historically, the way in which a new, politically powerful paradigm of research is able to seize a leading position in a plurality of cultural contexts is often by making previous approaches look obsolete and primitive. ${ }^{29}$ This has certainly been the strategy by which the economic approach to the law has been able to seize a global role, by offering an expansive, universalistic model that expresses itself in English (the new lingua franca) and which claims to be the latest natural legal order for the global age.

For the economic approach, law is supposed to create incentives for market actors and, more generally, to create economically efficient markets. Moreover, the merger of law and economics has produced a now diffused general understanding of law as a technology, a refurbished strategy for its de-politicization. While it would be grossly exaggerated to claim that efficiency reasoning enjoys a dominant role as an approach to legal scholarship worldwide, nevertheless there is evidence that it is the main intellectual vehicle used to diffuse expansionistic and universalistic American legal ideals. The new producers of global law, private and public international institutions of global governance (the WTO, World Bank, IMF, mega law firms, rating agencies, and so on) implement policy based on the value of legal efficiency.

Since the 1990s, the relationship between law and the market began to be gradually subverted in US legal theory. The law, it was posed, should be without values, efficient, and serve the function of facilitating rather than constraining transactions. As a consequence of this philosophy, the law should be 'market friendly', that is it should limit itself to protecting property rights, freedom of contracts and enterprise. The law should be adapted to the necessities of the market, domestically and in particular in the so-called 'emerging markets'. Today, because of this ideological revolution, carried out by leading American scholars and funded by conservative foundations, it is the corporate-dominated market that governs the law and not the other way around. Moreover, the re-emergence of development discourses caused intervention in developing legal systems to be actually encouraged ${ }^{30}$, and this thanks to the de-politicization of law carried out by international financial institutions.

Legal intervention always follows a top-down approach with intervening legal systems perceiving themselves (and often being perceived by local elites) as providing a superior model, a sophisticated recipe for progress. These interventions systematically proceed with no considerations of the local circumstances, and universalism in policy prescription denies differences and complexities in the areas of intervention, resulting in the construction of a naturally inferior 'other'.

\footnotetext{
${ }^{29}$ That happened to the French exegetic methodology, considered obsolete by the much more elegant 'scientific' German approach, dominant until World War II. That was possibly the case of Franco-German inspired 'social approach' to law, advertised as a step forward in civilization compared to the previous extremes of individualism and social Darwinism.

${ }^{30}$ See Luca Pes, Law and Development, Ph.D. Dissertation (University of Turin 2007); and A. Santos and DM Trubek (eds), The New Law and Economic Development; a Critical Appraisal (nt 10).
} 


\section{CONCLUSIONS}

In the complex spectrum of global law, both throughout the era of colonialism and neo-liberal US-led Western imperialism within a pattern of continuity, the rule of law, together with the theory of 'lack' and other powerful rhetorical arguments, has been used in order to legitimize political interventions and plunder in the 'emerging' economies. The sacred concept of rule of law, whose positive connotations are 'naturally' assumed, has been portrayed as the embodiment of a professional and neutral technology, thus being capable of substituting the lack of democratic legitimacy of the institutions that are protagonist in the creation of global law. But its dark side has never been shown or discussed. An imperial rule of law is now a dominant layer for the worldwide legal systems. It is produced, in the interest of international capital, by a variety of institutions, both public and private, all sharing a gap in political legitimacy sometimes referred to as 'democratic deficit'. ${ }^{31}$ At the same time, law has been constructively turned into a technology and a mere component of an economic system of capitalism, thus hiding its intrinsic political nature, and annulling the relevance of local political systems, now impotent in front of the dynamics of global law. The 'dry technology' of the rule of law penetrates worldwide legal systems without any political discussion at the local level, attempting to create the conditions for the development of market economies, often without success, and causing serious consequences for the less powerful.

Under the technology of the rule of law, in its imperial version capable of producing plunder, the essence of the United States' law hides. In the aftermath of World War II, there was a dramatic change in the pattern of Western legal development. Leading legal ideas once produced in continental Europe and exported through the colonized world are now, for the first time, produced in a common law jurisdiction: the United States. Clearly, the present world dominance of the United States has been economic, military and political first, and only recently legal, so that a ready explanation of legal hegemony can be found within a simple conception of law as a product of the economy. ${ }^{32}$ Furthermore, US law has been capable of expanding worldwide thanks to its prestige, the high level of professionalization of its attorneys and a series of procedural institutions, that benefit plaintiffs, that allow US courts to have a certain capacity to attract jurisdiction, while showing themselves as courts for universal justice. ${ }^{33}$

The general attitude of the United States has been a very ethnocentric one, and precisely that of showing itself as the guardian of a universal legality, which it is legitimized to export through

\footnotetext{
${ }^{31}$ See Alfred Aman, The Democratic Deficit (New York University Press, New York 2006).

${ }^{32}$ See JM Cohen (ed) and Karl Marx, Capital: a Critique of Political Economy (Penguin Classics, London 1992).

${ }^{33}$ There is a fundamental structure of U.S. law that makes it better suited to the framework of the global market: its high degree of decentralization. This is possibly the most original aspect of the fundamental structure of U.S. law. No other legal system in the world has developed a full-fledged federal judicial system as complete and sophisticated as the United States has. The co-existence of a large number of federal and state courts made issues of jurisdiction and choice of law the primary concern of the American legal profession. These are the same issues that are on the table of the lawyer approaching global problems. American lawyers already enjoy a legal culture and discourse that is broader than jurisdictional limits. In this scenario, the annexing of one more jurisdiction, wherever located, does not particularly change the U.S. lawyer's way of reasoning. The very structure of the American judicial process, moreover, decentralizes power and activity. A large variety of activities within litigation which are labeled 'official' in European legal systems, such as service of process, discovery and questioning of witnesses, are already private matters in American law. This powerful combination of adaptive forces makes the structure of American law sufficiently familiar so as not to be excessively feared, yet sufficiently ambiguous to be successful in the international legal landscape. See U Mattei, A Theory of Imperial Law: A Study on U.S. Hegemony and Latin Resistance (2003) 10 Indiana Journal of Global Legal Studies 383; and (2003) Global Jurist Frontiers <http://works.bepress.com/ugo_mattei/1>.
} 
its courts of law, scholarly production, military and political intervention, and through a set of US-centric international institutions. In recent times, in particular after September $11^{\text {th }} 2001$ and the declaration of the 'war on terror', the US rule of law has come under attack ${ }^{34}$, so that once admiring crowds of lawyers and intellectuals worldwide are now beginning to look upon the United States as an uncivilized old West from the perspective of legal culture, despite the professional prestige still enjoyed by the giant New York law firms and by the US academy.

Notwithstanding, there has been no decline in the rhetoric of the rule of law when it comes to foreign relations. Bringing democracy and the rule of law is still used as a justification to keep intruding in foreign affairs. The same can be said for the international financial institutions and their innumerable 'development' projects that come packaged with the prestigious wrapping of the rule of law.

A rethinking of the very idea of global law is necessary and it must derive from a revaluation of the local dimension, which is currently ignored by the neo-liberal model of development. The production of global law should change its direction, and follow a bottom-up approach, rather than a top-down one, thus being sensitive to the local particularities and complexities.

Western spectacular ideas of democracy and the rule of law should be rethought. On this planet, resources are scarce, but there would be more than enough for all to live well. Nobody would admire and respect someone who, at a lunch buffet for seven, ate 90 percent of the food, leaving the other guests to share an amount insufficient for one. In a world history of capitalism in which the rule of law has reproduced this precise 'buffet' arrangement on the large scale, admiring the instruments used to secure such an unfair arrangement seems indeed paradoxical. People have to be free to build their own economies.

There is nothing inevitable about the present arrangements and their dominant and taken-forgranted certainties. Indeed, it may be that the present legal and political hegemonies suffer from lack: the lack of world culture and of global political realism.

\footnotetext{
${ }^{34}$ See Ugo Mattei and Laura Nader, Plunder (nt 13) chapter 7.
} 